\title{
Strategi Komunikasi Antarpribadi Kepala Sekolah Terhadap Motivasi Kerja Pendidik Pada Smk DDI Polman
}

\author{
Yusril \\ Institut Agama Islam DDI Polewali Mandar \\ (e-mail-yusril@gmail.com)
}

\begin{abstract}
ABSTRAK
Penelitian ini mengungkap strategi komunikasi antarpribadi terhadap motivasi belajar kinerja pendidik pada SMK DDI Polewali. Penelitian ini bertujuan untuk mengetahui penerapan strategi komunikasi kelompok dalam meningkatkan motivasi belajar Seni Budaya siswa SMK DDI Polewali Mandar untuk mengetahui proses pelaksanaan strategi komunikasi kelompok dalam meningkatkan motivasi belajar Seni Budaya siswa SMK DDI Polewali Mandar. Penelitian ini adalah penelitian kualitatif, Penentuan informan dalam penelitian ini menggunakan teknik purposive sampling, Subjek penelitian adalah peserta didik SMK DDI Polewali. Teknik pengambilan data dilakukan dengan wawancara mendalam menggunakan pedoman wawancara. Hasil penelitian menunjukkan bahwa strategi komunikasi berperan penting dalam meningkatkan motivasi belajar seni budaya peserta didik SMK DDI Polewali.
\end{abstract}

Kata Kunci : Komunikasi, Motivasi Belajar

\section{PENDAHULUAN}

Peningkatan kualitas pendidik merupakan bagian dari kualitas pendidikan yang secara keseluruhan merupakan masalah yang dihadapi pemerintah. Oleh karena itu program peningkatan sumber daya manusia khususnya kualitas pendidik menjadi tema penting bagi kebijakan pemerintah. Pendidikan memiliki peranan yang sangat penting bagi perkembangan dan perwujudan diri individu, terutama bagi perkembangan bangsa dan negara. Kemajuan suatu kebudayaan bergantung kepada cara kebudayaan tersebut mengenali, menghargai dan memanfaatkan sumber daya manusia. Hal ini berkaitan erat dengan kualitas pendidikan yang diberikan kepada setiap siswa.

Sejalan dengan itu, upaya-upaya untuk meningkatkan kualitas pendidikan sesuai dengan UU No. 16 Tahun 2004 maka sebutan untuk guru diganti dengan kata pendidik. Mengingat pendidik merupakan pemeran utama dalam proses pembelajaran maka kompetensi pendidik dalam mengajar dapat dikaji secara mendalam. Hal ini disebabkan pendidik sebagai "agen" yang dapat memberikan perubahan pada siswa baik dari segi kognitif, afektif dan psikomotor yang pada akhirnya bermuara pada peningkatan kualitas pendidikan dalam pencapaian tujuan pendidikan.

Proses pendidikan menuju kearah pencapaian tujuan sebagaimana yang telah ditetapkan dalam Pasal 3 Undang-Undang Nomor 20 Tahun 2003 tentang Sistem Pendidikan Nasional 
menyatakan tentang fungsi dan tujuan pendidikan nasional sebagai berikut: Pendidikan Nasional berfungsi mengembangkan dalam rangka mencerdaskan kehidupan bangsa bertujuan untuk mengembangkan potensi siswa agar menjadi manusia yang beriman dan bertakwa kepada Tuhan Yang Maha Esa, berahlak mulia, sehat, berilmu, cakap, kreatif, mandiri dan menjadi warga negara yang demokratis serta bertanggung jawab.

Sistem pendidikan nasional harus mampu menjamin pemerataan kesempatan pendidikan, peningkatan mutu serta relevansi dan efisiensi manajemen pendidikan untuk menghadapi tantangan sesuai dengan tuntutan perubahan kehidupan lokal, nasional, dan global sehingga perlu dilakukan pembaharuan pendidikan secara terencana, terarah dan penemuan- penemuan baru dalam bidang ilmu dan teknologi. Kemajuan teknologi khususnya teknologi informasi dan komunikasi (TIK) yang meningkat menuntut kita untuk beradaptasi secara kreatif dan mencari pemecahan yang imajinatif.

Lebih jauh, UU No 14 tahun 2005 menyatakan bahwa pendidik adalah pendidik yang profesional, profesional adalah memiliki keterampilan mendesain pembelajaran, selain itu pendidik harus memfasilitasi dirinya dengan seperangkat pengalaman, keterampilan dan pengetahuan tentang keguruan sesuai keilmuan yang ditekuninya. Saat ini, sebagian pendidik dalam mengajar masih terkesan hanya gugur kewajiban. Baginya, bagaimana sebuah peristiwa pembelajaran dapat berlangsung. Mereka tidak perduli dengan latar belakang siswa dan karakteristiknya. (Mukhtar, 2010: 7)

Padahal pendidik adalah komponen yang sangat memengaruhi proses pendidikan. Hal ini memang wajar, sebab pendidik merupakan ujung tombak yang berhubungan langsung dengan siswa sebagai subyek dan objek belajar. Bagaimanapun bagus dan idealnya kurikulum pendidikan, bagaimanapun lengkapnya sarana dan prasarana pendidikan, tanpa diimbangi kemampuan pendidik dalam mengimplementasikan, maka semuanya akan kurang bermakna.

Interaksi dalam proses pembelajaran kata kuncinya terletak pada strategi komunikasi yang digunakan oleh pendidik. Seorang pendidik harus bisa menyampaikan pesannya secara tepat dan benar, tetapi apabila seorang pendidik tidak dapat menyampaikan pesan secara proporsional justru akan terkesan materi tersebut acak-acakan dan tidak akan menumbuhkan motivasi belajar siswa. Menurut (Pupuh Fathurrohman, 2007: 10)

Seorang pendidik tidak saja dapat mengandalkan kecakapan dalam berkomunikasi di depan kelas, tetapi juga harus pandai mengemas pesan yang akan dikomunikasikan. Produk pesan pembelajaran yang baik, harus dikemas dalam tiga ranah pembelajaran yaitu: kognitif, afektif, dan psikomotor. Kemudian pada masing-masing ranah, seorang pendidik harus mempunyai strategi dalam mengkomunikasikan kepada siswa sehingga siswa dapat termotivasi untuk belajar.

Persoalannya, banyak pendidik menghadapi kesulitan oleh karena masalah strategi komunikasi yang digunakan kurang tepat, akibatnya siswa kurang memperhatikan apa yang disampaikan oleh pendidik tersebut. Apalagi bila diingat bahwa komunikasi dalam interaksi proses pembelajaran itu harus bersifat khusus yakni edukatif. Persoalan ini bukan hanya menyampaikan fikiran-fikiran dan narasi, akan tetapi fikiran-fikiran dan narasi yang mendidik.

Sejalan dengan itu, para ahli menyebutkan bahwa interaksi pendidik dan siswa terletak pada komunikasi yang komunikatif. Efektifitas komunikasi pendidik dengan siswa merupakan keharusan, 
sebaiknya pendidik berkomunikasi kepada siswa dalam bahasa yang mudah dicerna, dan dimengerti sehingga siswa lebih termotivasi dalam proses pembelajaran tersebut.

Hal ini senada dengan hasil penelitian yang dilakukan oleh Bobby De Porter mengungkapkan bahwa manusia dapat menyerap suatu materi sebanyak 70\% (tujuh puluh persen) dari apa yang dikerjakan, 50\% (lima puluh persen) dari apa yang dilihat dan didengar, $10 \%$ (sepuluh persen) dari apa yang dibaca. Oleh sebab itu seorang pendidik harus memiliki sejumlah strategi komunikasi dalam melakukan pembelajaran. Strategi komunikasi yang digunakan bukan saja untuk mencapai tujuan pembelajaran, tetapi lebih jauh dari itu adalah dalam rangka menumbuhkan motivasi belajar siswa. (Mahmud, 2009: 64)

Motivasi dalam kegiatan belajar merupakan kekuatan yang dapat menjadi tenaga pendorong bagi siswa untuk mendayagunakan potensi- potensi yang ada pada dirinya dan potensi yang ada di luar dirinya untuk mewujudkan tujuan belajar. Sebaliknya siswa yang tidak atau kurang memiliki motivasi, umumnya kurang mampu bertahan untuk belajar lebih lama, kurang sungguh-sungguh di dalam mengerjakan tugas. Sikap yang kurang positif di dalam belajar ini semakin nampak ketika tidak ada orang lain (pendidik) yang mengawasinya. Oleh karena itu, rendahnya motivasi merupakan masalah dalam belajar, karena hal ini memberikan dampak bagi ketercapaian hasil belajar yang diharapkan sesuai dengan tahap perkembangannya.

Perkembangan siswa adalah perkembangan seluruh aspek kepribadiannya, siswa adalah organisme yang unik yang berkembang dimana tempo dan iramanya tidak sama. Proses pembelajaran dapat dipengaruhi oleh perkembangan siswa yang tidak sama itu, di samping karakteristik lain yang melekat pada diri siswa.

Siswa dengan segala perbedaannya seperti motivasi, minat, bakat, perhatian, harapan, latar belakang sosio-kultural, tradisi keluarga, menyatu dalam sebuah sistem belajar di kelas. Perbedaanperbedaan inilah yang wajib dikelola, diorganisir pendidik, untuk mencapai pembelajaran yang optimal. Pendidik harus menyadari bahwa perbedaan potensi bawaan siswa merupakan kekuatan untuk mengorganisasi strategi komunikasi demi terwujudnya pembelajaran yang ideal.

Dari hasil penelitian yang dilakukan oleh Baugh mengungkapkan bahwa: hanya 20\% (dua puluh persen) siswa yang mampu menguasai materi pelajaran secara keseluruhan dari penyajian pendidik, 50\% (lima puluh persen) menguasai setengah dari materi penyajian dan $30 \%$ (tiga puluh persen) yang lebih kecil penguasaannya terhadap materi yang disajikan oleh pendidik. Akibatnya, bagi siswa yang sedang dan kurang menguasai materi pelajaran tersebut akan mengalami kesulitan dalam belajar bahkan tidak memiliki motivasi dalam belajar. dalam (Darmawati, 2003: 13).

Sejalan dengan itu, hasil penelitian Michael Grinder pengarang "Righting the Education Conveyor Pelt' telah mengajar gaya-gaya belajar dan mengajar kepada banyak instruktur, ia mencatat bahwa dalam setiap kelompok yang terdiri dari 30 (tiga puluh) siswa, sekitar 6 (enam) siswa dengan sangat memuaskan, 22 (dua puluh dua) siswa mampu belajar cukup efektif dan 2 (dua) siswa lainnya mempunyai kesulitan dalam belajar, hal ini merupakan persoalan yang sering muncul, yang memerlukan pemecahan masalah dari seorang pendidik. (Aunurrahman, 2009: 191).

Pendidik sebagai seorang pembimbing belajar siswa dalam menghadapi masalah tersebut perlu mengadakan pendekatan. Salah satu strategi komunikasi yang dapat menyelesaikan masalah tersebut di atas adalah strategi komunikasi pendidik. Dengan strategi komunikasi pendidik siswa yang 
mengalami masalah dapat berinteraksi dengan siswa yang memiliki kemampuan belajar yang lebih baik sehingga motivasi belajarnya dapat meningkat. Dengan strategi komunikasi pendidik yang diterapkan, siswa yang mengalami masalah tersebut akan lebih memahami kekuatan dan kelemahan yang ada padanya untuk selanjutnya siswa tersebut akan mendapatkan perhatian dan perlakuan layanan kegiatan belajar yang berbeda dengan siswa lainnya.

\section{METODE PENELITIAN}

Tipe penelitian ini adalah penelitian yang bersifat kualitatif yang bertujuan untuk mendeskripsikan secara sistematis strategi komunikasi pendidik dalam meningkatkan motivasi siswa. Kegiatan pertama adalah mengumpulkan informasi aktual secara rinci yang menggambarkan gejala yang ada. Kemudian mengidentifikasi masalah dan memeriksa kondisi dan praktek-praktek yang berlaku.

Titik berat metode penelitian kualitatif adalah pada interview, observasi, dan suasana alamiah (catatan lapangan). Peneliti bertindak sebagai pengamat dengan membuat kategori perilaku, mengamati gejala- gejala dan mencatat segala aktivitas pendidik dan siswa.

Penelitian ini dilakukan di SMK DDI Polewali Mandar. Pendekatan dalam penelitian ini adalah pendekatan pada komunikasi pendidikan yaitu proses komunikasi yang berlangsung di mana terjadi interaksi antara pendidik dan siswa yang berisi pesan pendidikan dengan tujuan untuk mengubah perilaku siswa kearah positif, dengan kata lain bahwa tujuan pendidikan dapat tercapai dengan adanya proses komunikasi.

Jenis dan sumber data yang dibutuhkan dalam penelitian ini adalah Data Primer. Data primer adalah data yang diperoleh langsung dari informan terpilih sebagai sumber informasi, berupa wawancara mendalam (in-depth interview) tentang strategi komunikasi pendidik dalam hal ini komunikasi kelompok dalam meningkatkan motivasi belajar siswa SMK DDI Polewali Mandar.

Selain itu sangat diperlukan juga informasi dari kepala Sekolah SMK DDI Polewali Mandar sebagai pimpinan yang merumuskan dan menetapkan kebijakan. Informasi dari Wakil Kepala Sekolah, Kepala urusan kurikulum, Koordinator Bimbingan dan Konseling (BK), dan Kepala tata usaha. Untuk memperoleh data atau informasi, keterangan-keterangan dan data yang diperlukan peneliti mengutamakan teknik pengumpulan data sebagai berikut:

1. Wawancara mendalam (in-depth interview) yaitu teknik pengumpulan data dengan mengajukan pertanyaan kepada beberapa informan yang berhubungan dengan objek penelitian dengan menggunakan Voice Recorder. Wawancara mendalam dilakukan dengan menggunakan pedoman wawancara yang dibuat sebagai kerangka acuan (frame reference) dari masalah penelitian.

2. Observasi, yaitu teknik pengumpulan data melalui pengamatan baik dilakukan secara participant observation (peneliti terlibat langsung ) maupun non participant (tidak terlibat)?

3. Penelitian kepustakaan (library research) dengan mengumpulkan buku-buku, karya ilmiah, makalah yang memiliki relevansi dengan masalah yang sedang diteliti.

4. Dokumentasi merupakan teknik yang digunakan untuk mengumpulkan data melalui dokumendokumen, laporan, arsip baik tahunan, bulanan maupun harian yang dianggap mendukung serta 
melengkapi hasil penelitian yang dilakukan.

\section{HASIL PENELITIAN DAN PEMBAHASAN}

Dalam pelaksanaan suatu program, peran dan fungsi strategi merupakan salah satu faktor yang menentukan. Bahkan dapat dikatakan bahwa sukses tidaknya suatu program sangat ditentukan oleh jenis dan bentuk strategi yang dipilih. Strategi pada hakikatnya adalah perencanaan (planning) dan manajemen (management) untuk mencapai suatu tujuan. Tetapi untuk mencapai tujuan tersehut, strategi tidak berfungsi sebagai peta jalan yang hanya menunjukkan bagaimana taktik operasionalnya. (Onong Uchjana, 2003: 300)

Pada mulanya istilah strategi digunakan dalam dunia militer yang diartikan sebagai cara penggunaan seluruh kekuatan militer untuk memenangkan suatu peperangan. Secara bahasa, strategi bisa diartikan sebagai siasat, kiat, trik, atau cara. Sedang secara umum strategi ialah suatu garis besar haluan dalam bertindak untuk mencapai tujuan yang telah ditentukan (Pupuh Fathurrohman, 2007: 3). Strategi berbeda dengan taktik, jika kita memutuskan apa yang seharusnya kita kerjakan maka sesungguhnya kita memutuskan sebuah strategi, sedangkan jika kita memutuskan bagaimana mengerjakan sesuatu maka itulah yang disebut taktik. Berdasarkan uraian tersebut di atas dapat disimpulkan bahwa strategi adalah suatu skema atau skenario menuju sasaran yang akan dicapai.

Untuk melaksanakan strategi tersebut, dibutuhkan suatu bentuk komunikasi dalam menyam $\backslash$ paikan suatu pesan. Dalam proses komunikasi tersebut setiap manusia memerlukan kehadiran manusia lain untuk berkomunikasi, berkelompok saling bantu membantu dan memenuhi kebutuhannya. Usaha manusila untuk memenuhi kebutuhannya itu tidak bisa dilakukan sendiri sehingga memerlukan bantuan dan kerja sama dengan orang lain. Kondisi demikian mengharuskan manusia berkomunikasi antara satu dengan yang lainnya dalam lingkungan kelompok maupun kehidupan bermasyarakat yang leblih luas.

Komunikasi adalah inti dari sebuah interaksi sosial. Tidak mungkin melakukan interaksi sosial tanpa komunikasi. Sejak bangun tidur sampai menjelang tidur manusia berkomunikasi dengan orang lain termasuk dengan anggota keluarga, teman sekerja, pimpinan, relasi dan seterusnya, komunikasi akan berhenti pada saat kita tidur.

Mendefinisikan istilah komunikasi adalah seperti mencoba mendefinisikan tujuan kehidupan itu sendiri terdapat sejumlah besar penafsiran dan sudut pandang. Komunikasi merupakan suatu hal yang sangat mendasar dalam kehidupan manusia. Dan bahkan komunikasi telah menjadi suatu fenomena bagi terbentuknya suatu masyarakat atau komunitas yang terintegrasi oleh informasi dimana masing-masing individu dalam masyarakat itu sendiri berbagi informasi ('Information sharing) untuk mencapai tujuan bersama.

Definisi-definisi komunikasi cenderung menekankan salah satu dari dua perhatian yang berbeda. Definisi-definisi awal berasal dari kajian ilmiah tentang bagaimana informasi bisa ditransfer dari satu ke lain tempat sehingga ini mewakili suatu pandangan berbasis informasi. Komunikasi ini diturunkan dari suatu perspektif keprilakuan, maka komunikasi dipandang sebagai suatu perilaku, perbuatan disengaja untuk mendapatkan informasi dari seseorang (pendidik) ke orang lain (siswa). Sebaliknya, definisi-definisi yang lebih belakangan berasaM dari fenomenologis tentang 
pengembangan hubungan-hubungan antar prilbadi yang efektif sehingga ia mewakili suatu pandangan berbasis makna .

Suatu kenyataan bahwa komunikasi merupakan penghubung manusia yang sangat penting apakah dalam bentuk verbal atau non verbal, bersifat informatif atau persuasif, secara sengaja atau kebetulan, tatap muka atau melalui media yang jelas bahwa komunikasi merupakan mata rantai hubungan antara sesama manusia, komunikasi meliputi segala apa yang kita lakukan (Achmad, AS: 1992).

Menurut Effendy komunikasi adalah proses penyampaian suatu pesan dalam bentuk lambang bermakna sebagai paduan pikiran dan perasaan berupa ide, informasi, kepercayaan, harapan imbauan dan sebagainya lyang dilakukan seseorang kepada orang lain, baik langsung secara tatap muka maupun tak langsung melalui media, dengan tujuan mengubah sikap, palndangan, atau perilaku. Rosmawaty (2010:17)

Sedangkan menurut Hovland, Janis dan Kelley komunikasi adalah suatu proses dimana kita mengerti orang lain dan kemudian berusaha untuk dimengerti oleh mereka, ini dinamis berubah secara konstan dan membagi respon untuk situasi yang total. (Rosmawaty 2010: 18)

Adapun strategi komunikasi merupakan panduan dan perencanaan komunikasi (communication p!anni \ng') dan manajemen komunikasi (communication managemenf) untulk mencapai suatu tujuan. Untuk mencapai tujuan tersebut strategi komunikasi harus dapat menunjukkan bagaimana operasionalnya secara taktis harus dilakukan dalam arti kata bahwa pendekatan (approach) bisa berbleda sewaktu-waktu bergantung dari situasi dan kondisi.

Rogers mengemukakan bahwa strategi komunikasi sebagai suatu rencana atau rancangan untuk mengubah tingkah laku manusia dalam skala yang lebih besar melalui transfer ide-ide. Definisi yang dikemukakan oleh Rogers ini menekankan perlunya pembuatan strategi komunikasi yang mempertimbangkan secara seksama tahapan- tahapan perencanaan komunikasi. Dengan demikian kegiatan komunikasi perlu melihat perencanaan sebagai suatu manifestasi kesadaran dalam mengatur dan mengorganisasikan aktivitas manusia bagi pencapaian efisiensi.

Menurut Middleton dalam menyatakan bahwa strlategi komunikasi adalah sebuah kombinasi terbaik dari saluran dan pesan\-pesan yang dirancang untuk mencapai khalayak tertentu agar tujuan yang diinginkan tercapai. Pengertian ini merujuk pada pentingnya relevansi dlan keterkaitan antara unsur-unsur perencanaan komunikasi seperti salulran, pesan dan khalayak. Inti pengertian diatas adalah pentingnya pemilihan dan penyesuian saluran, isi pesan dan kondisi khalayak sas laran maupun dengan kemampuan sumber daya yang ada.

Untuk mantapnya strategi komunikasi, menyatakan bahwa segala sesuatunya harus dipertautkan dengan komponen-kom ponen yang merupakan jawaban terhadap pertanyaan dalam rumus Lasswel yaitu: who (siapa komunikatornya), says what (pesan apa), in which channel (media apa), to whom (siapa komunikannya), with what effect (efek apa yang diharapkan). (Syaiful Rohim,2009: 9)

Sejalan dengan itu Wilbur Schramm menampilkaln apa yang ia sebut "The condition of success in Communicatio”, yakni kondisi yang harus dipenuhi jika kita menginginkan agar suatu pesan membangkitkan tanggapan yang kita kehendaki. (Onong Uchjana, 2003: 41)

Kondisi tersebut dapat dirumuskan sebagai berikut: 
1. Pesan harus dirancang dan disampaikan sedemikian rupa, sehingga dapat menarik perhatian siswa.

2. Pesan harus \menggunakan lambang-lambang tertuju kepada pengalaman yang sama antara pendidik dan siswa sehingga sama- sama mengertinya

3. Pesan harus membangkitkan kebutuhan pribadi siswa dan menyarankan beberapa cara untuk memperoleh kebutuhan tersebut.

4. Pesan harus melnyarankan suatu jalan untuk memperoleh kebutuhan yang layak bagi \situasi kelompok di mana peserta didik berada pada saat ia d ligerakkan untuk memberikan tanggapan yang dikehendaki.

Jika pendidik sudah mengetahui sifat-sifat dari siswa, dan tahu pula efek apa yang kita kehendaki dari mereka, maka strategi untuk memilih cara mana yang kita ambil untuk berkomunikasi sangatlah penting, karena ini ada kaitannya dengan media yang harus pendidik gunakan.

Cara bagaimana pendidik berkomunikasi (how to communicate) pendidik bisa mengambil salah satu dari dua tatana $\backslash n$ komunikasi seperti yang digunakan Di SMK DDI Polewali Mandar yakni $\backslash$ strategi komunikasi tatap muka (face to face communication) dan komulnikasi kelompok.

Komunikasi tatap muka dipergunakan apabila pendidik mengharapkan efek perubahan tingkah laku (behaviour change) dari siswa. Dengan komunikasi tatap muka pendidik dapat mengetahui apakah siswa memperhatikan dan mengerti apa yang dikomunikasikan. Jika umpan baliknya positif, maka pendidik aklan mempertahankan strategi komunikasi yang dipergunakan dan memeliharanya supaya umpan balik yang digunakan tetap menyenangkan. Bila sebaliknya, maka pendidik akan mengubah strategi komunikasi agar tuj luan dari komunikasi tersebut dapat berhasil.

Strategi komunikasi tatap muka kekuatannya adalah dalam hal mengubah tingkah laku siswa, tetapi kelemahannya adalah bahwa siswa yang dapalt diubah tingkah lakunya sangat sedikit, atas dasar itulah pendidik dapat men\gubah strategi komunikasinya dengan membagi siswa menjadi kelompok-kelompok kecil sehingga dapat terjadi dialog dalam proses pembelajaran.

Sudjana mengemukakan beberapa faktor yang perlu dipertimbang kan dalam menentukan bentuk komunikasi adalah: (1) tujuan yang ingin dlicapai; (2) sifat bahan pelajaran; (3) sumber belajar yang tersedia; (4) klarakteristik kelas; (5) kemampuan pendidik itu sendiri. Akan tetapi pada aklhirnya, faktor kemampuan pendidik sangat berperan dalam menentukan ketepatan pemilihan setiap bentuk komunikasi dalam komunikasi pendidikan.

Komponen Dalam Pendidikan.Ada tiga komponen pokok pendidikan yang saling berkaitan dan saling mempengaruhi satu sama lain. Ketiga elemen itu meliputi (1) masukan, (2) proses, (3) output. Masukan berkaitan dengan faktor-faktor yang mempengaruhi proses belajar mengajar, proses berkaitan dengan cara bagaimana suatu pendidikan atau belajar mengajar berlangsung, dan output atau keluaran berkenaan degan hasil yang hendak dicapai dalam proses pembelajaran (tujuan-tujuan pendidikan) yang meliputi perubahan perilaku sebagai hasil belajar. Komponen-komponen pokok ini, ditemukan pada setiap bentuk pendidikan formal maupun non formal.

Komponen masukan, yang terdiri dari warga belajar (siswa), alat, lingkungan merupakan unsur dasar dari proses komunikasi pendidikan. Siswa terdiri dari umur, jenis kelamin, pengalaman, serta faktor-faktor kepribadian yang lain. Alat terdiri atas pendidik, peralatan, bahan belajar, dana program dan sebagainya. Lingkungan terdiri atas fisik, sosial budaya dan ekonomi. 
Komponen proses komunikasi yang merupakan inti dari kegiatan pendidikan, di dalamnya terjadi proses belajar mengajar. Kegiatan itu dapat berupa proses penyampaian pesan-pesan pengetahuan, sikap dan keterampilan. Melalui proses ini warga belajar atau siswa berangsur-angsur menguasai suatu keterampilan.

Atas dasar itu, maka proses komunikasi bagi siswa bermakna sebagai proses belajar karena di dalamnya terjadi proses penyampaian pesan-pesan yang berisi pengetahuan, sikap dan keterampilan. Jenis-jenis kegiatan belajar menurut Gagne terbagi atas: (1) belajar keterampilan motorik; (2) belajar bersikap; (3) belajar keterampilan intelektual (berkenaan dengan kaidah, konsep dan persepsi) (4) belajar informasi verbal; dan (5) belajar kegiatan intelektual. Jenis kegiatan belajar yang lain adalah (1) belajar pengetahuan atau kognitif, (2) belajar sikap atau afektif, (3) belajar keterampilan atau psikomotor.

Komponen output (hasil) merupakan tingkat kecakapan yang dicapai oleh siswa setelah mengkuti proses pembelajaran. Meliputi: (1) memiliki pemahaman yang sungguh-sungguh akan pesan yang disampaikan, (2) kemahiran mengenal, memilih dan menggunakan bahan belajar dengan baik, (3) mampu mengaplikasikan pengetahuan, sikap dan keterampilan mereka dalam kehidupannya. Komponen hasil sangat dipengaruhi oleh komponen masukan dan komponen proses. Tersedianya dan berfungsinya dengan baik komponen-komponen masukan dan proses dalam suatu kegiatan belajar mengajar, memungkinkan tercapainya hasil yang diharapkan.

Dalam proses pembelajaran sumber komunikasi adalah pendidik, walaupun ketika proses berjalan biasa terjadi komunikasi interaktif (timbal balik) antara pendidik dan siswa namun sumber komunikasi yang dominan adalah pendidik. Dampak yang diharapkan dari pelaksanaan proses pembelajaran adalah difahaminya materi pembelajaran oleh siswa yang telah disampaikan oleh pendidik sesuai dengan tujuan yang telah ditetapkan sebagaimana telah disusun dalam rencana pembelajaran.

Lebih lanjut Wilbur Schram dalam Wina Sanjaya menyatakan bahwa suatu proses atau kegiatan komunikasi akan berjalan baik apabila terdapat overlaping of interest (pertautan minat dan kepentingan) antara sumber dan penerima pesan. Untuk terjadinya overlaping of interest dituntut adanya persamaan tingkat relatif dalam hal kerangka referensi (frame of reverence) dari kedua pelaku komunikasi (pendidik dan siswa).

Kerangka referensi antara lain adalah tingkat pendidikan, pengetahuan, latar belakang budaya, kepentingan dan orientasi. Sehingga dalam hal ini pendidik harus memahami benar tentang kondisi siswanya agar pelaksanaan proses pembelajaran dapat berjalan efektif.

Ada tiga pola komunikasi yang dapat digunakan untuk mengembangkan interaksi dinamis antara pendidik dengan siswa, yaitu:

1. Komunikasi sebagai aksi atau komunikasi satu arah.

Dalam komunikasi ini pendidik berperan sebagai pemberi aksi dan siswa sebagai penerima aksi. Pendidik aktif dan siswa pasif. Ceramah pada dasarnya adalah komunikasi satu arah atau komunikasi sebagai aksi. Komunikasi jenis ini kurang dapat menghidupkan kegiatan siswa belajar.

2. Komunikasi sebagai interaksi atau komunikasi dua arah. 
Pada komunikasi ini pendidik dan siswa dapat berperan sama yaitu pemberi aksi dan penerima aksi. Di sini, sudah terlihat hubungan dua arah, tetapi terbatas antara pendidik dan siswa secara individual. Antara siswa tidak ada hubungan. Siswa tidak dapat berdiskusi dengan temannya. Namun antara pendidik dan siswa saling memberi dan menerima. Komunikasi ini lebih baik dari pada yang pertama, sebab kegiatan pendidik dan siswa relatif sama.

3. Komunikasi multi arah atau komunikasi sebagai transaksi.

Jenis komunikasi ini tidak hanya melibatkan interaksi dinamis antara pendidik dengan siswa tetapi juga melibatkan interaksi yang dinamis antara siswa yang satu dengan siswa yang lainnya. Proses belajar mengajar dengan pola komunikasi ini mengarah kepada proses pengajaran yang mengembangkan kegiatan siswa yang optimal, sehingga menumbuhkan siswa belajar aktif. Diskusi dan simulasi merupakan strategi yang dapat mengembangkan komunikasi ini. Pupuh (Fathurrohman, 2007: 39)

Komunikasi kelompok adalah komunikasi dalam sekelompok kecil orang dengan tujuan antara lain untuk berbagi informasi, membantu mengembangkan gagasan bahkan membantu memecahkan masalah, baik dilakukan secara formal maupun non formal. Komunikasi kelompok diperlukan karena setiap anggota dari suatu kelompok, pasti butuh komunikasi untuk berinteraksi dengan sesama anggota kelompoknya. Rosmawaty (2010: 86).

Menurut Brodbeek dan Lewin mendefinisikan kelompok dengan menggambarkannya sebagai kumpulan individu-individu yang mempunyai hubungan-hubungan tertentu yang membuat mereka saling ketergantungan satu sama lain dalam ukuran- ukuran yang bermakna. (Sitti Hartinah, 2009: 20)

Menurutnya, kelompok adalah untuk melangsungkan hidupnya karena dengan kelompok manusia dapat memenuhi kebutuhan, mengembangkan diri, mengembangkan potensi, serta aktualisasi diri. Hal tersebut bertolak dari pemikiran bahwa manusia merupakan mahluk sosial yang tetap memiliki keinginan untuk bergabung dengan orang lain untuk keinginan berkelompok.

Menurut Rosmawaty (2010: 93) kelompok kecil adalah kelompok komunikan sebagai berikut:

1. Lebih terorganisasi dan lebih terlembagakan daripada komunikan antar pribadi.

2. Lebih rasional dibandingkan dengan kelompok besar.

3. Jumlah orang tidak dapat ditentukan secara eksak, tetapi menurut Linzey Gardner lebih berdasarkan pada ukuran ruang (the room size), seperti dalam rapat, diskusi, kuliah dan lainlain.

4. Semakin banyak kesempatan anggota kelompok untuk dapat menyampaikan pendapatnya.

5. Saling berinteraksi satu sama lain dalam suatu pertemuan yang bersifat face to face, dimana setiap anggota mendapat kesan atau penglihatan antara yang satu dengan yang lainnya sama sehingga dapat memberikan tanggapan kepada masing-masing sebagai perorangan.

Komunikasi kelompok kecil (small group communication) merupakan proses komunikasi antar tiga orang atau lebih yang berlangsung secara tatap muka. Dalam kelompok tersebut anggota berinteraksi satu sama lain.

Tipe komunikasi ini oleh banyak kalangan dinilai sebagai pengembangan dari komunikasi antar pribadi. Peserta komunikasi berperan secara fleksibel sebagai pengirim dan penerima. Setelah 
orang ketiga bergabung di dalam interaksi tersebut, berakhirlah komunikasi antar pribadi dan berubah menjadi komunikasi kelompok kecil.

Untuk ukuran mengenai kelompok kecil, beberapa ahli memberikan batasan-batasan yang berbeda-beda. Menurut Devito kelompok kecil sebagai sekumpulan orang kurang lebih 5-12 orang, ukuran kelompok kecil menurut Kumar berkisar antara 15-25 orang dalam Wiryanto (2004: 45). Anggota-anggota kelompok kecil dapat berkomunikasi dengan mudah. Sumber dan penerima informasi dihubungkan dengan tujuan yang sama. Kelompok tersebut mempunyai alasan yang sama bagi anggotanya untuk berinteraksi. Komunikasi kelompok menitikberatkan pada tingkah laku individu dalam diskusi kelompok. Komunikasi ini hanya memusatkan perhatian pada proses komunikasi dalam kelompok-kelompok kecil.

Menurut Goldberg dalam Wiryanto (2004: 47) mengatakan bahwa komunikasi kelompok adalah suatu bidang studi, penelitian dan penerapan yang menitikberatkan, tidak hanya pada proses kelompok secara umum tetapi juga pada perilaku komunikasi individu-individu pada tatap muka diskusi kelompok kecil.

Sejalan dengan itu, Michael Burgoon juga mengemukakan bahwa komunikasi kelompok adalah interaksi secara tatap muka antara tiga orang atau lebih, dengan tujuan yang telah diketahui seperti berbagi informasi, menjaga diri, pemecahan masalah, yang mana anggota-anggotanya dapat mengingat karakteristik pribadi anggota-anggota yang lain secara tepat. (Wiryanto, 2004: 46).

Terdapat bermacam-macam jenis diskusi yang dapat digunakan dalam proses pembelajaran, antara lain:

1. Diskusi Kelas

Diskusi kelas atau disebut juga diskusi kelompok adalah proses pemecahan masalah yang dilakukan oleh seluruh anggota kelas sebagai peserta diskusi. Prosedur yang digunakan dalam jenis diskusi ini adalah: pertama, pendidik membagi tugas sebagai pelaksanaan diskusi misalnya siapa yang akan menjadi moderator, siapa yang menjadi penulis. Kedua, sumber masalah (pendidik, siswa, atau ahli tertentu dari luar) memaparkan masalah yang harus dipecahkan selama 10 sampai 15 menit. Ketiga, siswa diberi kesempatan untuk menangani permasalahan setelah mendaftar pada moderator. Keempat, sumber masalah member tanggapan, dan kelima, moderator menyimpulkan hasil diskusi.

2. Diskusi Kelompok Kecil

Diskusi kelompok kecil dilakukan dengan membagi siswa dalam kelompok-kelompok. Jumlah anggota kelompok antara 3 sampai 5 orang. Pelaksanaanya dimulai dengan pendidik menyajikan permasalahan secara umum, kemudian masalah tersebut dibagi-bagi ke dalam sub masalah yang harus dipecahkan oleh setiap kelompok kedi. Selesai diskusi kelompok kecil, ketua kelompok menyajikan hasil diskusinya.

3. Simposium

Simposium adalah metode mengajar dengan membahas suatu persoalan dipandang dari berbagai sudut pandang berdasarkan keahlian. Simposium dilakukan untuk memberikan wawasan yang luas kepada siswa. Setelah para penyaji memberikan pandangannya tentang masalah yang dibahas, maka simposium di akhiri dengan pembacaan kesimpulan hasil kerja tim perumus yang telah ditentukan sebelumnya. 


\section{Diskusi Panel}

Diskusi panel adalah pembahasan suatu masalah yang dilakukan oleh beberapa orang panelis yang biasanya terdiri dari 4 sampai 5 orang di hadapan audiens. Diskusi panel berbeda dengan jenis diskusi lainnya. Dalam diskusi panel audiens tidak terlibat secara langsung, tetapi beperan hanya sebagi peninjau, para panelis yang sedang melaksanakan diskusi. Oleh sebab itu, agar diskusi panel efektif perlu digabungkan dengan metode lain, misalnya dalam metode penugasan. Siswa disuruh untuk merumuskan hasil pembahasan dalam diskusi. (Wina Sanjaya, 2006: 157).

Dalam pelaksanaan suatu program, peran dan fungsi strategi merupakan salah satu faktor yang menentukan. Bahkan dapat di katakan bahwa sukses tidaknya suatu program sangat di tentukan oleh jenis dan bentuk strategi yang di pilih. Begitu pentingnya strategi MC. Nichols menyatakan bahwa strategi merupakan " decevtive device " yang berarti alat yang paling berbahaya dan riskan (Salusu, 1996 )

Pada mulanya istilah strategi di gunakan dalam dunia militer yang di artikan sebagai cara penggunaan seluruh kekuatan militer untuk memenangkan suatu peperangan. Konsep strategi berasal dari bahasa Yunani "strategos " yang berarti jenderal. Dalam konsep awalnya strategi memang banyak dikaitkan dengan dunia militer yakni upaya yang di tempuh oleh jenderal sebagai orang yang bertanggung jawab dalam peperangan. (Wahyudi. $1996: 16$ ).

Strategi berbeda dengan taktik, jika kita memutuskan sebuah strategi apa yang seharusnya kita kerjakan maka sesungguhnya kita memutuskan sebuah strategi, sedangkan jika kita memutuskan bagaimana mengerjakan sesuatu maka itulah yang di sebut taktik. Faturrohman mengemukakan bahwa strategi adalah suatu garis besar haluan dalam bertindak untuk mencapai tujuan yang telah di tentukan.

Pendapat lain dikemukakan Candler menjelaskan bahwa strategi merupakan alat untuk mencapai tujuan jangka panjang, program tindak lanjut serta prioritas alokasi sumber daya. Sedangkan Ahmad S. Adnan mengatakan bahwa arti strategi adalah bagian terpadu dari suatu perencanaan (planning) yang pada akhirnya perencanaan adalah salah satu fungsi dasar dari proses management. (Ruslan, 1999 :106 - 107)

Newman dan Logan mengemukakan empat unsur strategi dari setiap usaha, yaitu:

1. Mengidentifikasi dan menetapkan spesifikasi dan kualifikasi hasil (output) dan sasaran (target) yang harus dicapai, dengan mempertimbangkan asprasi dan seleramasyarakat yang memerlukannya.

2. Mempertimbangkan dan memilih jalan pendekatan utama (basic way) yang paling efektif untuk mencapai sasaran.

3. Mempertimbangkan dan menetapkan langkah-langkah (steps)yang akan ditempuh sejak titik awal sampai dengan sasaran.

4. Mempertimbangkan dan menetapkan tolok ukur (kriteria) dan patokan ukuran (standard) untuk mengukur dan menilai taraf keberhasilan usaha. (Rusyan, $1989: 55$ ).

Jika kita terapkan dalam konteks pembelajaran, keempat unsur tersebut adalah :

1. Menetapkan spesifikasi dan kualifikasi tujuan pembelajaran yakni perubahan profil prilaku dan prilaku peserta didik. 
2. Mempertimbangkan dan memilih system pendekatan pembelajaran yang dipandang paling efektif.

3. Mempertimbangkan dan menetapkan langkah-langkah atau prosedur, metode dan teknik pembelajaran.

4. Menetapkan norma-norma dan batas minimum ukuran keberhasilan atau kriteria dan ukuran baku keberhasilan.

Berdasarkan uraian tersebut di atas dapat disimpulkan bahwa strategi adalah suatu skema atau skenario untuk mencapai sasaran yang akan dituju.

\section{PENUTUP}

\section{A. Simpulan}

Berdasarkan hasil penelitian, diperoleh kesimpulan bahwa aborsi Kriminalis Provokatus pada remaja Putri di Kota Polewali Mandar adalah sebagai berikut:

1. Pengetahuan informan menunjukan kurang baik mengenai aborsi yang dilakukan,dan dampak dari aborsi. Empat melakukan tindakan kejahatan, tapi kurangnya pengetahuan mereka menganggap hal biasa tidak berbahaya.

2. Sikap yang permisif terhadap aborsi, sikap informan yang permisif menganggap aborsi tidak boleh dilakukan karena itu berbahaya namun mereka tetap memutuskan untuk melakukan hal tersebut karena berbagai alasan seperti atas dasar paksaan ,takut,malu dan belum mau punya anak.

3. Akses media informasi mengenai aborsisangatmendukung, dan memudakan remaja untuk mengakses dan membaca,tentang aborsi dan tempat aborsi, ada dua informan yang mengaku pernah mengakses media serta membicarakan hal-hal yang berkaitan dengan seksualitas,dan aborsi.

\section{B. Saran}

Berdasarkan hasil penelitian terkait Abortus Kriminalitas, maka disarankan sebagai berikut.

1. Membuka wawasan baru tentang kesehatan reproduksi remaja yaitu dapat dimulai dengan membaca dari berbagai sumber tentang informasi tersebut yang nantinya dapat disampaikan kepada anak sebagai bekal ilmu maupun pencegahan dari masalah seksualitas remaja.

2. Pelaku aborsi agar dihukum berat ,Hukuman berat tersebut menjadi contoh bagi orang lain yang berkeinginan melakukan aborsi sehingga mereka menjadi takut untuk melakukannya.

3. Untuk Dinas Pendidikan Kota Polewali Mandar Mencanangkan kebijakan baru berkaitan dengan pendidikan kesehatan reproduksi untuk remaja misalnya dengan menyisipkan materi pendidikan kesehatan reproduksi dalam kegiatan ekstrakurikuler sebagai upaya untuk mencegah terjadinya Aborsi pada remaja di Kota Polewali Mandar.

\section{DAFTAR PUSTAKA}

Achmad, AS. Manusia dan Informasi. Ujung Pandang: Hasanuddin University Press, 1992. 
Ali, Tahir. Perkembangan Anak Usia Sekolah. Jakarta: Ghalia Indonesia, 2004.

Arikunto, Suharsimi. Prosedur Penelitian Suatu Pendekatan Praktek. Jakarta: Rineka Cipta, 1999.

Arifin, Anwar. Paradigma Baru Pendidikan. Jakarta: PoksiVI Fpg DPR-RI, 2003.

Aunurrahman. Belajar Dan Pembelajaran. Bandung: Alfabeta, 2009.

Bahri, Saeful. Guru dan Anak Didik Dalam Interaksi Edukatif (Suatu Pendekatan Teoritis). Jakarta: Rineka Cipta, 2005.

Bulaeng, Andi, Metode Penelitian Komunikasi Kontemporer. Makassar: Hasanuddin University, Press, 2000,

Burhan, Jazir, Peningkatan Mutu Pendidikan Melalui Penataran Guru. Analisis Pendidikan, Thn.1. No 2. Brent D. Ruben. Communication and Human Behavior. New York: Macmilland Publishing Company, 1988.

Cangara, Hafied. Pengantar Ilmu Komunikasi. Jakarta: Raja Grafindo, 2002.

Danim S. Inovasi Pendidikan. Bandung: CV. Pustaka Setia, 2002. 2002.

Danim Sudarwan. Media Komunikasi Pendidikan. Jakarta: Bumi Aksara, 2008.

Darmawati. Hubungan Antara Profesionalisme Guru Dengan Prestasi Belajar Siswa SM A Negeri di Kabupaten Maros. Tesis. Makassar: PPs Universitas Negeri Makassar, 2003.

Dedi, Supriyadi. Mengangkat Citra dan Martabat Guru. Yogyakarta: Adicita Karya Nusa, 1999.

Depdikbud. Profil Kemampuan Dasar Guru.Jakarta: P3G, 1980.

Depdiknas. Undang-undang RI No 20 Tahun 2003 Tentang Sistem Pendidikan Nasional. Jakarta: Depdiknas, 2003.

Devito, Joseph. A. Kuliah Dasar Edisi Kelima, Alih Bahasa Agus Maulana. Jakarta: Profesional Books, 1997.

Djamarah, S.B. Prestasi belajar dan Kompetensi Guru. Surabaya: Usaha Nasional, 1994.

Drost. Sekolah: Mengajar atau Mendidik. Yogyakarta: Kanisius, 1998.

Effendy. Uchjana Onong. Ilmu, Teori dan Filsafat Komunikasi. Bandung: Citra Aditya Bakri, 2003.

Fathurrohman, Pupuh. Strategi Belajar Mengajar, Konsep Umum dan Konsep Islami. Jakarta: PT. Refika Aditama, 2007.

Forsdale, Bandung. Perspectives on Communication. New York: Random House, 1981.

Freud. S. The ego and the id. London: The Hogarth Press, 1950.

Hamalik, Oemar. Proses Belajar Mengajar. Jakarta: Bumi Aksara, 2001.

Hanafi, Abdullah. Memahami Komunikasi Antar Manusia. Surabaya: Usaha Nasional, 1984.

Harsey, Paul dan Blancharc Ken, Manajemen Perilaku Organisasi Pendayagunaan Sumber Daya Manusia. Jakarta: Erlangga, 1992.

Hartinah, Sitti. Konsep Dasar Bimbingan Kelompok. Bandung: PT.Refika Aditama, 2009.

Indrawidjaya, Adam. Perilaku Organisasi. Bandung: Sinar Baru, 1986.

Kartini, Kartono. Pemimpin dan Kepemimpinan. Jakarta: Rajawali, 1997.

Kazim Ashar. Pengukuran Efektifitas Dalam Organisasi. Pusat Antar Universitas Ilmu-Ilmu Sosial. Jakarta: Universitas Indonesia, 1993. 
Kunandar. Guru Profesional (Implementasi KTSP dan Persiapan Menghadapi Sertifikasi Guru). Jakarta: CV. Rajawali, 2007.

Mahmud. Penerapan Strategi Komunikasi Pembelajaran Kontekstual Pada Bidang Studi Biologi Di SMP Negeri 13 Makassar. Tesis. Makassar. PPs Universitas Hasanuddin, 2009.

Malik, Tahir. Metodologi Penelitian Dan Aplikasi. Makassar: Pustaka Pena Press, 2010.

Malik ,Tahir. Perencanaan Strategis SDM Dalam Organisasi. Makassar: Kretakupa Print Makassar, 2010.

Mappa, Syamsu. Aspirasi Pendidikan dalam Hubungannya dengan Prestasi Belajar Siswa. Disertasi. Jakarta: PPS IKIP Jakarta, 1979. 